\title{
Encotyllabe spari do not live in Brazil: Morphological and molecular evidence confirm two new species of Encotyllabe (Monogenea: Capsalidae) from Brazil
}

\author{
Naraiana L. Taborda \\ Universidade Federal Rural do Rio de Janeiro: Universidade Federal Rural do Rio de Janeiro
}

Fabiola A. Sepulveda

Universidad de Antofagasta

Jose L. Luque

Universidade Federal Rural do Rio de Janeiro

Ruben Escribano

Universidad de Concepcion

Marcelo Enrique Oliva ( $\square$ marcelo.oliva@uantof.cl )

Universidad de Antofagasta https://orcid.org/0000-0003-1759-2797

\section{Research}

Keywords: Monogenea, Encotyllabe haemuli n. sp., Encotyllabe yamagutii n. sp., Orthopristis ruber, Pagrus pagrus, Southwestern Atlantic, Host specificity

Posted Date: September 28th, 2020

DOI: https://doi.org/10.21203/rs.3.rs-82727/v1

License: (c) (i) This work is licensed under a Creative Commons Attribution 4.0 International License. Read Full License 


\section{Abstract}

Background

Currently, 24 species of Encotyllabe Diesing, 1850 (Monogenea: Capsalidae) are listed in WoRMS, but the validity of many species has been questioned due to deficient or incomplete descriptions. On the other hand, almost all species in the genus have been described from one host species or closely related host species, suggesting host specificity, but other species, specifically Encotyllabe spari Yamaguti, 1934, have been reported at least from 19 species belonging to nine families in two orders (Perciformes and Scorpaeniformes) from Japan, the Arabian Gulf and Brazil. Concerning Brazilian records of Encotyllabe spari (but also as Encotyllabe cf. spari); seven host species belonging to four families and two orders have been reported as hosts for this species. The aim of this study was to describe two new species of Encotyllabe from Brazil, previously considered as E. spari.

\section{Methods}

During 2016, we examined specimens of Orthophristis ruber (Cuvier) (Haemulidae) and Pagrus pagrus (Linnaeus) (Sparidae) caught off the coast of Cabo Frio, Rio de Janeiro, Brazil by local fishermen. Specimens of Encotyllabe were collected from the pharyngeal plates of the hosts. Morphological and morphometric (multivariate analysis of proportional measurements standardized by total length) and molecular analysis (LSUrRNA and cox 1 gene) were performed in order to identify the collected monogenea.

\section{Results}

The presence of two new species of Encotyllabe, Encotyllabe yamagutiin. sp. and Encotyllabe haemuli n. sp., parasitizing the pharyngeal plates of Pagrus pagrus and Orthopristis ruber, respectively, is strongly suggested by the three approaches used in this study. The main morphological differences from the most related species include a combination of body size, shape of the penis, and size and position of the testes.

\section{Conclusions}

Specimens of Encotyllabe, hitherto recorded as E. spari or E. cf. spari, belong to two new species. Our results suggest that the host specificity for members of Encotyllabe and specimens registered as E. spari, other than those from the original description, must be revisited.

\section{Background}

To date, 24 species of Encotyllabe Diesing, 1850 (Monogenea: Capsalidae) are listed in WoRMS [1]; of those, E. masu Ishii and Sawada, 1938, described from a Salmonid, should not be taken into consideration [2], and Encotyllabe callaoensis Tantalean, 1974 was described in an unavailable, short-lived journal (just a single issue). Thus, both species are not considered herein as valid. The first four species described in the genus, namely, $E$. nordmanni Diesing, 1850, from Brama rail (Bonnaterre) in the Mediterranean Sea; E. pagelli Van Beneden and Hesse, 1863, from Pagellus centrodontus (Brünnich) in Brest, France; E. paronae Monticelli, 1907, from Crenilabrus pavo (Linnaeus), in Geneve; and E. vallei Monticelli, 1907, from Chrysophrys aurata (Linnaeus) in Trieste, were so briefly described or illustrated that their similarities to, and differences from, other species are difficult to assess, and thus they should be considered provisional species. For instance, and as previously noted [3], E. nordmanni was described as "longit. Corp 11/2, latit 1/2, longit. pedic. Acet 1/2." The same applies for E. pricei, E. chironemi, 
E. lintoni, E. monticelli, E. pricei, E. fotedari and E. punctatai, which have been considered species inquirenda because they were poorly described and are based on only one or two specimens [3-9]. E. lintoni was described based on one anomalous specimen bearing one testis [10] and redescribed [11] based on the same specimen from the original description. E. chironemi was described from one specimen from Chironemus spectabilis (= Cheilodactylus spectabilis Cheilodactylidae) caught in Cook Strait, New Zealand [9] and redescribed on the basis of ten measured specimens obtained from the related Nemadactylus macropterus caught in Coffs Harbour, Australia, more than $2200 \mathrm{~km}$ apart from the type locality [8].

The status of those provisional species must be confirmed following redescriptions based on specimens from the type host and locality due to the expected host specificity of Capsalids [12] as well as the appreciable geographic variation observed in some species of monogeneans $[13,14]$. Consequently, 12 species of Encotyllabe are considered herein as valid: E. antofagastensis Sepúlveda, González \& Oliva, 2014, E. caballeroi Velasquez, 1977, E. carangis Pillai and Pillai, 1976, E. caranxi Lebedev, 1967, E. cheilodactyli Sepúlveda, González \& Oliva, 2014, E. embiotocae Noble, 1966, E. kuwaitensis Khalil and Abdul-Salam, 1988, E. Iutjani Tripathi, 1959, E. pagrosomi MacCallum, 1917, E. souzalimae Carvalho and Luque, 2012, E. spari Yamaguti, 1934 and E. xiamenensis Li, Yan \& Wang, 2004. The most reliable taxonomic criteria for mature specimens of Encotyllabe are, among others, body shape, relative size of several organs, shape and position of testes, distance between the center of the ovary and center of the testis, penis shape and length of pedicel when extended [3-9]. However, multivariate analysis of proportional measurements standardized by total length as well as molecular studies will strongly improve the taxonomy of Encotyllabe[3,15].

The following species of Encotyllabe have been recorded from marine fish in Brazil: Encotyllabe spari in Haemulon sciurus, Orthopristis ruber, Anisotremus surinamensis, Conodon nobilis (Haemulidae), Pagrus pagrus (Sparidae), Menticirrhus americanus, Micropogonias furnieri (Sciaenidae) and Dactylopterus volitans (Dactylopteridae); Ecf. spari in O. ruber, E. lintoni in P. pagrus, and E. suozalimae in Trichiurus lepturus (Trichiuridae) and Thyrsitops lepidoides (Gempylidae) [7, 15-26].

Since Encotyllabe spari have been reported from Brazilian fish belonging to seven species in four families and two orders (Perciformes and Scorpaeniformes), we searched for this species in P. pagrus and O. ruber, the most common reported hosts in Brazil, in order to confirm their identity. Fresh material allowed us to perform molecular as well as morphological and morphometric analyses. Our results indicated that specimens previously reported as E. spari in P. pagrus and $O$. ruber belong to two new species. These are described and differentiated below.

\section{Methods}

\section{Sample collection and processing}

During 2016 and aperiodically, 26 specimens of Pagrus pagrus and 9 specimens of Orthopristis ruber were obtained from local fishermen off Cabo Frio, Rio de Janeiro, Brazil. In the laboratory, fish were dissected; gills and pharyngeal plates were removed and examined under a stereomicroscope for monogeneans. Thirty-four specimens of two species of Encotyllabe obtained from $P$. pagrus $(\mathrm{n}=16)$ and 0 . ruber $(\mathrm{n}=18)$ were selected for morphological and molecular analyses.

Some worms were fixed in $4 \%$ neutral buffered formaldehyde and then transferred and stored in $70 \%$ ethanol for further morphological studies (light microscopy). Selected specimens from each of the two host species were 
transferred to $96 \%$ ethanol for DNA analysis.

Population descriptors, prevalence and mean intensity [27] were recorded.

\section{Morphological and statistical analysis}

Fixed specimens were stained with carmine, cleared with clove oil (Sigma-Aldrich, Taufkirchen, Germany) and mounted in Eukitts ${ }^{\circledR}$ (O. Kindler GmBH, Freiburg, Germany). Drawings were made with the aid of an Olympus BX53 microscope (Olympus Corporation, Tokyo, Japan) equipped with a drawing tube. Measurements are given in micrometers unless otherwise stated with a range followed by the mean in parentheses. Type-material was submitted to the Helminthological Collection Instituto Oswaldo Cruz (CHIOC) - Rio de Janeiro - Brazil.

To comply with the regulations set out in article 8.5 (version 2012) of the International Code of Zoological Nomenclature (ICZN), details of the paper have been submitted to ZooBank. The LSID (Life Science Identifier) is

\section{Morphometric analysis}

Multivariate morphometric analyses were performed on 16 specimens from $O$. ruber and nine from $P$. pagrus. Principal component analysis (PCA) was used for proportional morphometric measurements [28]. Because of the expected correlation between the size of different organs and body length (BL, excluding peduncle), we used proportion rather than raw measurement [3]. The proportion measurements were as follows: (1) maximum body width/BL, (2) length of the peduncle/BL, (3) diameter of haptor/BL, (4) diameter of the anterior attachment organs/BL, (5) pharynx width/BL, (6) length of the ovary/BL, (7) ovary width/BL, (8) length of the testes/BL, (9) width of the testes/BL, (10) length of the large hamulus/BL, (11) length of the small hamulus/BL, and (12) length of the marginal hooks/BL. PCA was performed using the Statistic 7.0 software (Statsoft Inc., Tulsa, Oklahoma).

\section{Molecular data and phylogenetic analyses}

DNA was isolated from each individual following a modified protocol [29] involving treatment with sodium dodecyl sulphate, digestion with proteinase $\mathrm{K}, \mathrm{NaCl}$ protein precipitation and subsequent ethanol precipitation. DNA was eluted in nuclease-free water and quantified in a Biospec-nano spectrophotometer. For molecular analyses, the nuclear LSU rDNA and mitochondrial gene cytochrome coxidase 1 ( $\operatorname{cox} 1$ ) were used. The LSUrRNA gene was amplified with the forward primer C1 (5'-ACCCGCTGAATT $\neg$ TAAGCAT-3') and reverse primer D2 (5'TGGTCCGTGTT $\neg$ TCAAGAC-3') [30]. The cox1 gene was amplified with the forward primer ASmit1 (5'TTTTTTGGGCATCCTGAGGTTTAT-3') and reverse primer ASmit2 (5'-TAAAGAAAGAACATAATGAAAATG-3') [31]. Each PCR had a final volume of $35 \mu \mathrm{l}$, including five standard units of GoTaq DNA polymerase (Promega, Madison, USA), $7 \mu \mathrm{l} 5 \times$ PCR buffer, $5.6 \mu \mathrm{lgCl}_{2}(25 \mathrm{mM}), 2.1 \mu \mathrm{l}$ BSA (10 mg/ml), $0.7 \mu \mathrm{l}$ of deoxynucleotide triphosphate (dNTP) (10 mM), 10 pM of each primer, $3 \mu$ template DNA and sufficient nuclease-free $\mathrm{H}_{2} \mathrm{O}$ to reach a total volume of $35 \mu \mathrm{l}$. A Boeco Ecogermany M-240R Thermal Cycler (Boeckel, Hamburg, Germany) was used to carry out PCR. Amplification for each molecular marker follow [30] and [32] for the LSU rRNA and cox 1 gene, respectively. Both DNA strands were directly sequenced (Macrogen, Seoul, Korea; http://www.macrogen.com). Sequences were edited and contigs assembled using ProSeq v 2.91 beta [33]. New sequences were deposited in GenBank (see Table I for accession numbers).

For each gene, a database was constructed in FASTA format (new generate sequences + sequences of Encotyllabe spp. from GenBank) and aligned with Clustal X [34]. Then, a visual inspection was performed with 
ProSeq v.2.91 [33] in order to edit the length of the final data set.

Phylogenetic reconstructions were conducted in a concatenate gene matrix ( LSU rRNA + cox 1) performed in Mesquite v.2.75 [35]. Bayesian inference (BI) was analyzed with MrBayes [36] and maximum likelihood (ML) analysis with W-IQ-TREE [37].

$\mathrm{BI}$ analyses were executed with the following parameters: $\mathrm{nst}=6$, rates $=$ invgamma according to the evolutionary model determined by jModeltest 0.1 .10 for each gene; that is, TVM+ G for $L S U$ rRNA and TIM1+I for cox 1 and replaced by $\mathrm{GTR}+\mathrm{G}+\mathrm{I}$ for MrBayes. The analysis was performed for 5,000,000 generations. Analyses included two runs of four chains and sampling every 100 generations. Support for nodes in the BI tree topology was obtained by posterior probability burn-in of the initial $25 \%$ of samples. Visual inspection of log likelihood scores against generation time was performed in TRACER v.1.7 [38]. Statistical support for ML analyses was performed with 1,000 bootstraps. The trees were visualized and edited in FigTree v.1.4.4 [38]. The pairwise p-distances and numbers of nucleotide differences between Encotyllabe species were calculated using MEGA v6 [39] (Table 2). Two species of Neobenedenia (Capsalidae) were used as outgroups (Table 1).

For comparative purposes, vouchers of Encotyllabe spari from Brazil deposited in the Helminthological Collection of the Oswaldo Cruz Institute (CHIOC) from P. pagrus (CHIOC 34531), Haemulon sciurus (Shaw) (CHIOC 32019, 32064, 32068), Anisotremus virginicus (Linnaeus) (CHIOC 37947), and Conodon nobilis (Linnaeus) (CHIOC 37948) were studied.

\section{Results}

Class Monogenea (van Beneden, 1858)

Family Capsalidae Baird, 1853

Genus Encotyllabe Diesing, 1850

Encotyllabe yamagutii n. sp.

Type-host. Pagrus pagrus (Linnaeus) (Perciformes: Sparidae), red porgy.

Type-locality. Cabo Frio, Rio de Janeiro, Brazil $\left(22^{\circ} 55^{\prime} \mathrm{S}, 41^{\circ} 58^{\prime} \mathrm{W}\right)$.

Type-material. Holotype (CHIOC xxxxxxx) and 3 paratypes (CHIOC xxxxx - xxxxxx) were submitted to the Helminthological Collection Instituto Oswaldo Cruz.

Site in host: Pharyngeal plates.

Prevalence and intensity. Prevalence: 69\%; mean intensity 1.5.

Representative DNA sequences. MT968928 (LSU rRNA)

Etymology. This species is named in honor of Dr. Satyu Yamaguti for his distinguished contributions to the study of monogeneans.

\section{Description}


[Measurements based on nine mounted and stained adult worms]. Body ellipsoidal 1.77-2.50 (1.94) long; 7001120 (890) wide. Anterior attachment organs bearing two muscular suckers, 150 (130-180) in diameter, in each anterolateral margin of the head region and surrounded by an incomplete membrane. Haptor pedunculate, bellshaped 450-590 (490) in diameter, with thin marginal membrane 27-39 (35) long, peduncle 620 (560-650) long (Fig. 1A). Haptor armed with a pair of large hamulus, 210-270 (250) long; small hamulus 29-32 (30) long and 14 homogeneously distributed marginal hooklets 11-15 (13) long (Fig. 1 C-E). Mouth surrounded by digitiform processes leading to a pharynx of irregular shape and 170-240 (230) in diameter. Intestinal caeca branched not confluent posteriorly. Two pairs of eyespots at the level of pharynx. Testes oval, side by side and anteriorly midlevel of body proper 250-360 (300) long and 140-240 (210) wide. Goto's glands not observed. Vas deferens sinistral winding anteriorly, entering at the base of the penis and enlarging to form an internal seminal vesicle. Prostatic duct joins ejaculatory duct and opens at the tip of the penis. Penis muscular 240-340 (300) long; 90110 (100) in wide, penis with prolongation oriented to the anterior region of the body. Genital pore ventral on the left side of the pharynx. Ovary oval, pretesticular, immediately posterior to the vitelline reservoir 90-160 (120) long, 130-190 (170) wide, with an intraovarian seminal receptacle (Fig.1 B). Uterus extends anterolaterally along the posterior wall of the penis bulb. Ootype not observed, apparently hidden by Mehlis' gland, slender uterus opens at genital pore. Vaginal pore on ventral side at level of vitelline reservoir; ducts not observed. Vitelline reservoir preovarian on the left side. Vitelline follicles extensive laterally and median fields, from penis to base of peduncle. Eggs not observed.

\section{Differential diagnosis}

Encotyllabe yamagutii $\mathrm{n}$. sp. resembles those species with testes side by side, located anterior to the midlevel of the body, and a peduncle larger than the haptor diameter, namely, E. spari and E. antofagastensis. The main differences between the new species and the abovementioned species are the shape of the penis with a projection near the genital pore in the new species and the body size, with E. yamagutii being smaller (1.94 mm) than E. spari $(3.14 \mathrm{~mm})$ and $E$. antofagastensis $(2.43 \mathrm{~mm})$. Moreover, the vitelline receptacle is definitively preovarian in $E$. spari and $E$. antofagastensis but anterolateral in the new species. Molecular analysis of concatenated genes shows that E. antofagastensis and E. yamagutii are well discriminated species (Fig. 3). Unfortunately, molecular data for E. spari are not available in GenBank,

The type host for E. spari is Sparus microcephalus (Sparidae), but it is also found in two non-related hosts in the Inner Sea (Japan): the haemulid Plectorhynchus pictus and serranid Epinephelus akaara. The type host for $E$. antofagastensis is the haemulid Anisotremus scapularis from the southeastern Pacific. The new species is also a parasite of a sparid (Pagrus pagrus) but from the coast of Brazil.

Examination of specimens from $P$. pagrus identified by several authors as E. spari (CHIOC 34531) has revealed that they in fact belong to the new species.

\section{Encotyllabe haemulii n. sp.}

Type-host. Orthopristis ruber (Cuvier) (Perciformes: Haemulidae), corocoro grunt.

Type-locality. Cabo Frio, Rio de Janeiro, Brazil (2255’S, $\left.41^{\circ} 58^{\prime} \mathrm{W}\right)$.

Type-material. Holotype (CHIOC xxxxxxx) and 3 paratypes (CHIOC xxxxx - xxxxxx) were submitted to the Helminthological Collection Instituto Oswaldo Cruz. 
Site in host: Pharyngeal plates.

Prevalence and intensity. Prevalence: 100\%; mean intensity 4.75.

Representative DNA sequences. MT968927 (LSU rRNA), MT967362, MW000907-MW000909 (cox1)

Etymology. This species is named after the host family.

\section{Description}

\section{Encotyllabe haemulin. sp.}

[Measurements based on 16 stained and mounted adult worms]: Body bell-shaped, tapered anteriorly and wide posteriorly 2.74-3.60 (3.19) long; 810-1.65 (1.23) wide. Anterior attachment organs bearing two muscular suckers 180-300 (250) in diameter, in each anterolateral margin of the head region and surrounded by an incomplete membrane. Haptor pedunculate, bell-shaped 470-780 (660) in diameter, with a thin marginal membrane 45-76 (62) long, peduncle 650-400 (540) long (Fig. 2A). Haptor armed with a pair of large hamuli 250-340 (280) long; small hamulus 24-30 (28) long and 14 homogeneously distributed marginal hooklets 1013 (12) (Fig. 2 D-F). Mouth surrounded by digitiform processes leading to a globular pharynx 270-450 (390) in diameter. Intestinal ceca branched not confluent posteriorly. Two pairs of eyespots at the level of the pharynx. Testes oval, side by side and anteriorly midlevel of body proper 130-180 (150) long and 100-170 (120) wide. Goto's glands not observed. Vas deferens sinistral winding anteriorly, entering at the base of the penis, enlarging to form an internal seminal vesicle. Prostatic duct joins ejaculatory duct and opens at the tip of the penis. Penis muscular 180-230 (210) long and 89-120 (110) wide. Genital pore ventral on the left side of the pharynx. Ovary oval, pretesticular, immediately posterior to the vitelline reservoir, 170-210 (180) long and 180-260 (220) wide, with an intraovarian seminal receptacle (Fig. 2B). Uterus extends anterolaterally along the posterior wall of the penis. Vaginal pore on ventral side of the vitelline reservoir; ducts not observed. Vitelline reservoir preovarian, sinistral. Vitelline follicles extensive laterally and in median fields, from the pharynx to the base of peduncle. Eggs pyramidal, with 4 long and twisted filaments (Fig. 2C).

\section{Differential diagnosis}

Only two species of Encotyllabe have been described with testes smaller than the ovary, namely, E. embiotocae and $E$. caranxi. Of those, E. caranxi is the longest species described in the genus $(11.26 \mathrm{~mm})$; the type host is a carangid (Caranx lutescens) from the Great Barrier (Australia), whereas the type host for E. haemuli is a haemulid from the coast of Brazil. The relationship between large and small haptoral hooks in E. embiotocae varies between 6.8:1 on average, whereas this value reaches 10:1 in the new species, with the smaller hooks in the new species being proportionally smaller.

Specimens of Encotyllabe previously identified as E. spari from Anisotremus virginicus, Conodon nobilis and Haemulon sciurus deposited in CHIOC and identified as $E$. spari in fact belong to the new species. Specimens identified as E. spari [17] also belong to E. haemuli.

\section{Morphometric analysis}

Figure 3 presents the plot of specimens in the bidimensional axis of the PCA. The first and second components explain $59.5 \%$ of the total variance. The first component explains $37.3 \%$ of the variance and was mainly 
associated with the proportional morphometric measurements of the ovary width/BL, attachment organs average/BL, testes length/BL, testes width/BL, large hamulus length/BL, and marginal hooks length/BL. The second component explains $22.2 \%$ of the variance and was associated with haptor diameter/BL and body width/BL. The new species, E. yamagutii and E. haemuli, showed some overlap but were clearly differentiated.

\section{Molecular and phylogenetic analyses.}

For the LSUrRNA, five sequences were obtained, three from E. haemuli (852 bp) and two from E. yamagutii (865 bp). The intraspecific genetic variability for both species was $0 \%$. Four sequences for cox 1 were obtained from $E$. haemuli (437 bp long). Concatenated analysis based on $\mathrm{ML}$ and BI produced trees with similar topology (Fig. 4). Each of the new species was statistically supported in independent clades $(\mathrm{ML}>90 ; \mathrm{B} \mid>0.9)$. Table 2 indicates pairwise genetic divergence for LSUrRNA and the cox1 gene.

\section{Discussion}

In general, monogeneans are among the most host-specific parasites and may be the most host-specific of all fish parasites [40]. When broad host specificity, i.e., many hosts for the same species, of Monogenea is studied under molecular scrutiny, that broad specificity is questioned. For instance, the "cosmopolitan" capsalid Neobenedenia melleni, recorded from more than 100 host species in five orders, may be a complex of species, as suggested by molecular studies [12], and the related Benedenia seriolae, recorded as a parasite of natural populations of Seriola spp. in Japan, Australia, and Chile as well as in farmed conditions around the world, is also a species complex, as demonstrated by molecular evidence [41.42]. When the hosts for the herein recognized species of Encotyllabe were analyzed, an interesting picture became evident: five species (E. anisotremi, E. carangis, E. cheilodactyli, $E$. Iutjani, and E. xiamenensis) have been recorded from one host species [3, 5, 44], and two species have been recorded from two different but related host species. E. caranxi was found in three species of Caranx and one of the related Pseudocaranx (Carangidae) [5], and E. embiotocae was found to be a parasite of Cymatogaster aggregata and Amphistichus argenteus (Embiotocidae) [4]. Exceptions are E. caballeroi, reported as a parasite of three species of Lethrinus, Gymnocranius audleyi (Lethrinidae) and Scolopis monogramma and Scolopis sp. (Nemipteridae) from Australia, New Caledonia, the Philippines and Vietnam [5, 45, 46]; E. kuwaitensis, a parasite of Caranx sexfasciatus, Caranx sp. (Carangidae) and Plectorhinchus schotaf (Haemulidae) from the Arabian Gulf and the Mediterranean sea [6, 47]; and E. souzalimae, which has been reported from two nonrelated hosts from Brazil: Trichiurus lepturus (Trichiuridae) and Thyrsitops lepidopoides (Gempylidae) [7, 24). E. pagrosomi has been recorded from seven host species belonging to three families from the Galapagos Islands, Mexico (Pacific coast), Australia, Venezuela and Peru $[5,48,49]$. Finally, E. spari has been recorded from at least 25 host species in nine families and two orders in Japan, the Arabian Gulf, Brazil, Vietnam, Venezuela, Argentina and the Mediterranean sea [5-7, 15-26, 47, 49, 50, 51]. With regard to the Brazilian records, E. spari (but also E. cf. spari) has been recorded from at least four species of Haemulidae, Conodon nobilis, Anisotremus surinamensis, Haemulun sciurus and Orthropristis ruber, one species of Sparidae, Pagrus pagrus (Sparidae); two species of Sciaenidae (Menticirrhus americanus, Micropogonias furnieri); and one species of Dactylopteridae (Dactylopterus volitans) $[15,16,20,22,25,26]$ (Table 3). Our data challenge the low host specificity of Encotyllabe from Brazil; worms from the Sparid Pagrus and those from the Haemulid Orthopristis ruber belong to different species, as demonstrated by molecular tools (Fig. 3). Surprisingly, the two species from Haemulidae (E. haemuli and E. antofagastensis) form a well-supported clade, presenting additional evidence of high host specificity. 
The taxonomic status of members of Encotyllabe is not easy to clarify, as traditional taxonomy is based on body shape, the relative sizes of several organs, the shape and relative position of the testes, the penis shape, the extension of the vitellaria, and the size and shape of the anchors as well as the relative distances between different organs [3-9]. Additional characteristics, such as the relative position of the testes, have also been suggested, but multivariate analysis (i.e., principal component analysis) of proportions of different organs in relation to body size, rather the analysis or comparison of raw measurements, will be an adequate tool to discriminate species in this genus [3] as well as in the Monopisthocotylea Acanthocotyle [43], as suggested by our results (Fig. 4). Our results confirming the host specificity of Encotyllabe suggest that previous records of E. spari in hosts other than Pagrus pagrus and Orthopristis ruber could represent new species. This finding also applies to other species, particularly E. spari, E. pagrosomi and E caballeroi with nonrelated hosts and from different geographical localities.

\section{Declarations}

\section{Ethics approval and consent to participate:}

This study was conducted under the protocol of the Ethical Commission of the Universidad de Antofagasta, Antofagasta, Chile.

\section{Consent for publication:}

Not applicable

\section{Availability of data and materials:}

Data supporting the conclusions of this article are included within the article. The sequences generated in this study were deposited in the GenBank database under the accession numbers MT967362 (E. haemuli) (cox1 gene), MT968927 (E. haemuli), MT968928 (E. yamagutii), MT982166 (E. antofagastensis), MT982167 (E. cheilodactyli), MT982168 (Neobenedenia sp.1) (LSU rRNA gene)

\section{Competing interests:}

The authors declare that they have no competing interests

\section{Funding:}

Grant Grant 5303 “Programa Semilleros de Investigación” DGI, Universidad de Antofagasta, funded this study. The Millennium Institute of Oceanography (IMO-Chile) grant, ICM-ANID, ICN12_019-IMO

\section{Authors' contributions:}

NLT and JLL initiated the research and obtained the samples, NLT, JLL, RE and MEO performed the descriptions and morphological analyses. FAS conducting molecular analyses. All authors read and approved the final manuscript. 


\section{Acknowledgements:}

We thank Tomáš Scholz (Institute of Parasitology, České Budějovice) for helpful suggestions to an early draft of the manuscript. NLT was supported by a student fellowship from CNPq (Conselho Nacional de Desenvolvimento Científico e Tecnológico, Brazil).

\section{Conclusions}

Two new species of the genus Encotyllabe are described from the pharyngeal plates of two teleosts from Cabo Frio, Rio de Janeiro, Brazil. Both species were previously reported as Encotyllabe spari or Encotyllabe cf. spari from seven species belonging to four families and two orders from Brazil. The status of some species must be confirmed after redescriptions based on materials from the type host and locality. Encotyllabe seems to be highly specific, and additional studies using molecular and multivariate morphometric analyses must be performed, specifically for species reported from nonrelated hosts and different geographical localities.

\section{Abbreviations}

CHIOC: Coleccion Helmintologica Instituto Oswaldo Cruz; PCA: Principal component analysis, LSU rRNA: cox1: cytochrome c oxidase subunit 1 gene; PCR: polymerase chain reaction; BI: Bayesian inference; ML: maximum likelihood; TVM+ G: transversion model + Gamma distribution; TIM1+I = transition model + Invariant site; $\mathrm{GTR}+\mathrm{G}+\mathrm{I}$ = General Time Reversible Model + Gamma distribution + invariant sites.

\section{Declarations}

Ethics approval and consent to participate: This study was conducted under the protocol of the Ethical Commission of the Universidad de Antofagasta, Antofagasta, Chile.

Consent for publication: Not applicable

Availability of data and materials: Data supporting the conclusions of this article are included within the article. The sequences generated in this study were deposited in the GenBank database under the accession numbers MT967362 (E. haemuli) (cox1 gene), MT968927 (E. haemuli), MT968928 (E. yamagutii), MT982166 (E. antofagastensis), MT982167 (E. cheilodactyli), MT982168 (Neobenedenia sp.1) (LSU rRNA gene)

Competing interests: The authors declare that they have no competing interests

Funding: Grant Grant 5303 “Programa Semilleros de Investigación” DGI, Universidad de Antofagasta, funded this study. The Millennium Institute of Oceanography (IMO-Chile) grant , ICM-ANID, ICN12_019-IMO

Authors' contributions: NLT and JLL initiated the research and obtained the samples, NLT, JLL, RE and MEO performed the descriptions and morphological analyses. FAS conducting molecular analyses. All authors read and approved the final manuscript.

Acknowledgements: We thank Tomáš Scholz (Institute of Parasitology, České Budějovice) for helpful suggestions to an early draft of the manuscript. NLT was supported by a student fellowship from CNPq (Conselho Nacional de Desenvolvimento Científico e Tecnológico, Brazil). 


\section{References}

1. WoRMS Editorial Board. World Register of Marine Species. Available from http://www.marinespecies.org at VLIZ. Accessed 2020-08-15. DOI:10.14284/170.

2. Bychowsky BE. Monogenetic Trematodes, their Systematics and Phylogeny. Izdatel'stvo Akademii Nauk SSSR, Moscow. (In Russian: English translation edited by Hargis, W.J. Jr., 1961), 627 pp.

3. Sepúlveda FA, González MT, Oliva ME. Two new species of Encotyllabe (Monogenea: Capsalidae) based on morphometric and molecular evidence: parasites of two inshore fish species of northern Chile. J Parasitol, 2014; 100: 344-9.

4. Noble ER. The genus Encotyllabe (Class Trematoda) with a description of a new species. Trans Am Microsc Soc, 1966; 85: 144-51.

5. Egorova TP. Recent composition of the subfamily Encotyllabinae (Monogenea: Capsalidae). Parazitologiya, 2000; 34: 295-301. (In Russian.)

6. Khalil LF, Abdul-Salam JB. The subfamily Encotyllabinae (Monogenea: Capsalidae) with the description of Alloencotyllabe caranxi n. g., n. sp. and Encotyllabe kuwaitensis n. sp. Syst Parasitol, 1988; 11:139-150.

7. Carvalho AR, Luque JL. Three new species of monogeneans parasitic on Atlantic cutlassfish Trichiurus lepturus (Perciformes: Trichiuridae) from Southeastern Brazil. ActaSci Biol Sci, 2012; 34: 359-65.

8. 8, Williams A, Beverley-Burton. Redescription of three species of the genus Encotyllabe (Capsalidae: Monogenea) from fishes of the east coast of Australia. Aust J Zool, 1989; 37: 45- 53.

9. Robinson ES. Some Monogenetic Trematodes from Marine Fishes of the Pacific. Trans Am Microsc Soc, 1961; 80: 235-66.

10. Monticelli FS. II genere Encotyllabe Diesing. Annuario del Museo Zoologico della R. Universita di Napoli (Nuova Serie), 1907; Vol 2 (20): 1-13.

11. Price EW. North American monogenetic trematodes III. The family Capsalidae (Capsaloidea). J Wash Acad Sci, 1939; 29: 63-92.

12. Whittington ID. The Capsalidae (Monogenea: Monopisthocotylea): a review of diversity, classification and phylogeny with a note about species complexes. Folia Parasitol, 2004; 51: 109-22.

13. Rohde K, Watson N. Morphology and geographical variation of Pseudokuhnia minorn. g, n. comb. (Monogenea: Polyopisthocotylea). Int J Parasitol, 1985; 15: 557-67,

14. Rohde K, Watson N. Morphology, microhabitats and geographical variation of Kuhnia spp. (Monogenea: Polyopisthocotylea). Int J Parasitol, 1985; 15: 569-86.

15. Camargo ACA, Luque JL, Santos CP. Mexicana rubra sp. nov. and Encotyllabe cf. spari loff Rio de Janeiro. Helminthologia, 2017; 54: 336 - 47.

16. Kohn A, Abramson B, Macedo B. Studies on some monogenean parasites of Haemulon sciurus (Shaw, 1803) (Pomadasyidae). J Helminthol, 1984; 58: 213 - 18.

17. Luque JL, Amato JFR, Takemoto RM. Comparative analysis of the communities of metazoan parasites of Orthopristis ruberand Haemulon steindachneri (Osteichthyes: Haemulidae) from the southeastern Brazilian littoral: I. Structure and influence of the size and sex of hosts. Rev Bras Biol, 1996; 56: 279-92.

18. Kohn A, Cohen SC. South American Monogenea - list of species, hosts and geographical distribution. Int J Parasitol, 1998; 28: 1517- 54. 
19. Fábio S. Redescrição de Encotyllabe lintoni Monticelli, 1909 (Monogenea, Capsalidae) em Pagrus pagrus (Linnaeus, 1758).Bol Museu Nac, 1998; 385: 1-5.

20. Chaves ND, Luque JL. Ecology of metazoans parasites of Menticirrhus americanus (Osteichthyes: Sciaenidae), coast area from Rio de Janeiro State, Brazil.Rev Bras Parasitol Vet, 1999; 8: 137-44.

21. Paraguassú AR, Luque JL, Alves DR. Community ecology of the metazoan parasites of red porgy, Pagrus pagrus (L., 1758) (Osteichthyes, Sparidae), from the coastal zone, state of Rio de Janeiro, Brazil. ActaSci Biol Sci. 24, 2002; 2: 461-7.

22. Cohen SC, Justo MCN, Kohn A. South American Monogenoidea Parasites of Fishes, Amphibians and Reptiles. Fundacion Oswaldo Cruz, 2013; 663 pp.

23. Cordeiro A, Luque JLL. Metazoários parasitos do coió Dactylopterus volitans (Linnaeus, 1758) (Osteichthyes: Dactylopteridae) do litoral do Estado do Rio de Janeiro, Brasil. Acta Sci Biol Sci, 2005; 27: 119-23-

24. Domingues SA, Alves D. Metazoários parasitos de Thyrsitops lepidopoides (Osteichthyes: Gempylidae) do litoral do Estado do Rio de Janeiro, Brasil, Cadernos UniFOA, 2015; 27: 95-103.

25. Paschoal F, Cezar AD, Luque JL. Checklist of metazoan associated with grunts (Perciformes, Haemulidae) from the Nearctic and Neotropical regions. Check List, 2015; 11: 1501.

26. Soares IA, Luque JL. Seasonal variability of the composition and structure of parasite communities of red porgy, Pagrus pagrus (Perciformes: Sparidae) off Brazil. Helminthologia, 2015; 52: 236 - 43.

27. Bush AO, Lafferty KD, Lotz JM, Shostak AW. Parasitology meets ecology on its own terms: Margolis et al. Revisited. J Parasitol, 1997; 83: 575 - 83.

28. Quinn GP, Keough MJ. Experimental design and data analysis for biologists. Cambridge University Press, Cambridge, U.K., 2002; $556 \mathrm{p}$

29. Miller SA, Dykes DD, Polesky HFRN. A simple salting out procedure for extracting DNA from human nucleated cells. Nucleic Acids Res, 1988; 16: 1215.

30. Chisholm LA, Morgan JAT, Adlard RD, Whittington ID. Phylogenetic analysis of the Monocotylidae (Monogenea) inferred from 28S rDNA sequences. Int J Parasitol, 2001; 31: 1537-47.

31. Littlewood DTJ, Rohde K, Clough KA. Parasite speciation within or between host species? Phylogenetic evidence from site-specific polystome monogeneans. Int J Parasitol, 1997; 27: 1289-97.

32. Verneau O, Du Preez LH, Laurent V, Raharivololoniaina L, Glaw F, Vences M. The double odyssey of Madagascan polystome flatworms leads to new insights on the origins of their amphibian hosts. Proc R Soc B, 2009; 276: 1575-83.

33. Filatov DA. Proseq: A software for preparation and evolutionary analysis of DNA sequence data sets. Mol Ecol Notes, 2002; 2: 621-4.

34. Larkin MA, Blackshields G, Brown NP, Chenna R, McGettigan PA, McWilliam H, et al.

35. Clustal W and Clustal X version 2.0. Bioinformatics, 2007; 23: 2947-48.

36. Maddison WP, Maddison DR. Mesquite: a modular system for evolutionary analysis. Version 2.75, 2011; http://mesquiteproject.org.

37. Huelsenbeck JP, Ronquist F. MRBAYES: Bayesian inference of phylogenetic trees. Bioinformatics. $2001 ; 17$ :754-5.

38. TrifinopoulosJ, NguyenLT, von Haeseler A, Minh BQ. W-IQ-TREE: a fast online phylogenetic tool for maximum likelihood analysis Nucleic Acids Res, 2016; 44: 232-5. 
39. Rambaut A, Drummond AJ, Xie D, Baelee G, Suchard MA. Posterior Summarization in Bayesian Phylogenetics Using Tracer 1.7. Syst Biol, 2018; 67: 901-904.

40. Tamura K, Peterson D, Peterson N, Stecher G, Nei M, Kumar S. MEGA5: Molecular evolutionary genetics analysis using maximum likelihood, evolutionary distance, and maximum parsimony methods. Mol Biol Evol, 2011; 28: $2731-39$.

41. Whittington ID, Cribb BW, Hamwood TE, Halliday JA. 2000. Host-specificity of monogenean (Platyhelminthes) parasites: a role for anterior adhesive areas? Int J Parasitol, 2000; 30, 305-320.

42. Sepulveda FA, Gonzalez, MT. Molecular and morphological analyses reveal that the pathogen Benedenia seriolae (Monogenea: Capsalidae) is a complex species: Implications for yellowtail Seriola spp. aquaculture. Aquaculture, 2014; 418-419: 94 -100.

43. Baeza JA, Sepúlveda FA, González MT. The complete mitochondrial genome and description of a new cryptic species of Benedenia Diesing, 1858 (Monogenea: Capsalidae), a major pathogen infecting the yellowtail kingfish Seriola lalandi Valenciennes in the South-East Pacific. Parasites Vectors, 2019; 12: 490.

44. Ñacari LA, Sepúlveda FA, Escribano R, Oliva ME. Two new species of Acanthocotyle Monticelli, 1888 (Monogenea: Acanthocotylidae), parasites of two deep-sea skates (Elasmobranchii: Rajiformes) in the SouthEast Pacific. Parasites Vectors, 2019; 12: 512.

45. Li L, Yan J, Wang H. A new species of Encotyllabe from marine fishes in Minnan. Taiwan Bank,Fujian,China. J Zhejiang Univ-SC A, 2003; 31:207-10.

46. Rohde K, Hayward C, Heap M, Gosper D. A tropical assemblage of ectoparasites: gill and head parasites of Lethrinus miniatus (Teleostei, Lethrinidae). Int J Parasitol, 1994; 24: 1031-53.

47. Justine JL, Beveridge I, Boxshall GA, Bray RA, Moravec F, Whittington ID. An annotated list of fish parasites (Copepoda, Monogenea, Digenea, Cestoda and Nematoda) collected from Emperors and Emperor Bream (Lethrinidae) in New Caledonia further highlights parasite biodiversity estimates on coral reef fish. Zootaxa, 2010; 2691: 1-40

48. Kardousha MM, Al-Ansi MA, Al-Khayat. Monogenea of the Arabian Gulf Fishes. 3. Encotyllabe spari and E. kuwaitensis (Capsalidae) from Qatari waters. Riv Parassitol, 2002; 19: 227-35.

49. Faustino KD, Martinez RR, Tantaleán M. Monogeneos parásitos en Caulolatilus affinis (Jenyns, 1840), (Malacanthidae) de Puerto Cabo Blanco, Piura, Perú. Peruv J Parasitol, 2015; 23: 38-53.

50. Centeno L, Bashirullah AK, Alvarez ME, Álvarez R. Análisis comparativo de las comunidades de parásitos metazoarios en dos especies de peces marinos del Golfo de Cariaco, Venezuela. Bioagro, 2002; 14: $135-44$.

51. Canel D, Levy E, Soares IA, Braicovich PE, Haimovicic M, Luque JL, Timi JT. Stocks and migrations of the demersal fish Umbrina canosai (Sciaenidae) endemic from the subtropical and temperate Southwestern Atlantic revealed by its parasites. Fish Res, 2019; 214: 214-18.

52. Mahmoud NE, Mahmoud AM, Fahmy MM. Parasitological and Comparative Pathological Studies on Monogenean Infestation of Cultured Sea Bream (Sparus aurata, Spariidae) in Egypt. Oceanography, 2014; 2: 129.

53. Mollaret I, Jamieson BG, Adlard RD, Hugall A, Lecointre G, Chombard C, Justine J.L.Phylogenetic analysis of the Monogenea and their relationships with Digenea and Eucestoda inferred from 28S rDNA sequences. Mol Biochem Parasitol, 1997; 90: 433-38.

54. Perkins EM, Donnellan SC, Bertozzi T, Chisholm LA, Whittington ID. Looks can deceive: molecular phylogeny of a family of flatworm ectoparasites (Monogenea: Capsalidae) does not reflect current morphological 
classification. Mol Phylogenet Evol, 2009; 52: 705-14.

55. Olson PD, Littlewood DT. Phylogenetics of the Monogenea - evidence from a medley ofMolecules. Int J Parasitol, 2002; 32: 233-44.55. Sepulveda FA, Gonzalez MT. DNA barcoding evidence for the first recorded transmission of Neobenedenia sp. from wild fish species to Seriola lalandicultured in an open recirculating system on the Coast of Northern Chile. Aquaculture, 2018; 501: 239-46.

\section{Tables}

Table 1. GenBank accession numbers for sequences ( $L S U$ rRNA gene and cox1 gene) for Encotyllabe spp. and the species of the outgroup used in phylogenetic analyses.

\begin{tabular}{|c|c|c|c|c|c|c|}
\hline & & & & GenBank ID & & \\
\hline Specie & Host & Family & Country & $\operatorname{cox} 1$ & LSU rRNA & Reference \\
\hline $\begin{array}{l}\text { E. haemulin. } \\
\text { sp. }\end{array}$ & $\begin{array}{l}\text { Orthopristis } \\
\text { ruber }\end{array}$ & Haemulidae & Brazil & $\begin{array}{l}\text { MT967362 } \\
\text { MW000907- } \\
09\end{array}$ & MT968927 & $\begin{array}{l}\text { This } \\
\text { study }\end{array}$ \\
\hline $\begin{array}{l}\text { E. yamagutii n. } \\
\text { sp. }\end{array}$ & Pagrus pagrus & Sparidae & Brazil & - & MT968928 & $\begin{array}{l}\text { This } \\
\text { study }\end{array}$ \\
\hline $\begin{array}{l}\text { E. } \\
\text { antofagastensis }\end{array}$ & $\begin{array}{l}\text { Anisotremus } \\
\text { scapularis }\end{array}$ & Haemulidae & Chile & JQ782838 & MT982166 & $\begin{array}{l}\text { [3] / This } \\
\text { study }\end{array}$ \\
\hline E. caballeroi & $\begin{array}{l}\text { Gymnocranius } \\
\text { audleyi }\end{array}$ & Lethrinidae & Australia & - & AF026112 & {$[52]$} \\
\hline E. caranxi & $\begin{array}{l}\text { Pseudocaranx } \\
\text { dentex }\end{array}$ & Carangidae & Australia & - & FJ971990 & [53] \\
\hline E. cheilodactyli & $\begin{array}{l}\text { Cheilodactylus } \\
\text { variegatus }\end{array}$ & Cheilodactylidae & Chile & JQ782842 & MT982167 & $\begin{array}{l}\text { [3] / This } \\
\text { study }\end{array}$ \\
\hline E. chironemi & $\begin{array}{l}\text { Chironemus } \\
\text { marmoratus }\end{array}$ & Chironemidae & Australia & - & AF382054 & [54] \\
\hline $\begin{array}{l}\text { Neobenedenia } \\
\text { sp. } 1\end{array}$ & $\begin{array}{l}\text { Cheilodactylus } \\
\text { variegatus }\end{array}$ & Cheilodactylidae & Chile & JQ782846 & MT982168 & $\begin{array}{l}\text { [41] / } \\
\text { This } \\
\text { study }\end{array}$ \\
\hline $\begin{array}{l}\text { Neobenedenia } \\
\text { sp. } 2\end{array}$ & $\begin{array}{l}\text { Paralabrax } \\
\text { humeralis }\end{array}$ & Serranidae & Chile & MG735627 & MK202450 & [55] \\
\hline
\end{tabular}

Table 2. Percent pairwise genetic distances between Encotyllabe spp. for LSUrRNA gene (under the diagonal) and the mitochondrial cox 1 gene (above the diagonal). Bp pairwise differences between parentheses. 


\begin{tabular}{|llllllll|}
\hline \multicolumn{2}{|c}{ Species } & 1 & 2 & 3 & 4 & 5 & 6 \\
\hline 1 & Encotyllabe haemulin. sp. & & - & - & - & $7(18.8)$ & $9.2(24.8)$ \\
\hline 2 & Encotyllabe yamagutii n. sp. & $0.9(7)$ & & - & - & - & - \\
\hline 3 & E. caballeroi & $1.3(10)$ & $1.4(11)$ & & - & - & - \\
\hline 4 & E. caranxi & $1.6(6)$ & $1.9(7)$ & $2.5(9)$ & & - & - \\
\hline 5 & E. antofagastensis & 0 & $0.9(7)$ & $1.3(10)$ & $1.6(6)$ & & $9.5(25.6)$ \\
\hline 6 & E. cheilodactyli & $0.6(5)$ & $1.1(9)$ & $1.3(10)$ & $1.6(6)$ & $0.6(5)$ & $0.5(4)$ \\
\hline 7 & E. chironemi & $0.4(3)$ & $0.8(6)$ & $1.1(9)$ & $1.6(6)$ & $0.4(3)$ & 0.5 \\
\hline
\end{tabular}

Table 3. Encotyllabe spp. accepted as valid in this study, recorded hosts, host family, locality and reference. Most of the references previous 2000, follow Egorova (2000) [5]. 


\begin{tabular}{|c|c|c|c|c|}
\hline Species & Recorded hosts & Host Family & Locality & Reference \\
\hline $\begin{array}{l}\text { E. } \\
\text { antofagastensis }\end{array}$ & Anisotremus scapularis & Haemulidae & Chile & 3 \\
\hline E. caballeroi & Gymnocranius audleyi & Lethrinidae & Australia & 5 \\
\hline E. caballeroi & Lethrinus miniatus (*) & Lethrinidae & $\begin{array}{l}\text { Australia; New } \\
\text { Caledonia }\end{array}$ & $5,46,47$ \\
\hline E. caballeroi & Lethrinus nebulosus & Lethrinidae & Philippines & 5 \\
\hline E. caballeroi & Scolopsis monogramma & Nemipteridae & Australia & 5 \\
\hline E. caballeroi & Scolopsis sp. & Nemipteridae & Vietnam & 5 \\
\hline E. caranxi & Caranx lutescens & Carangidae & Australia & 5 \\
\hline E. caranxi & Caranx sexfaciatus & Carangidae & Mediterrano & 5 \\
\hline E. caranxi & Caranx sp. & Carangidae & Australia & 5 \\
\hline E. caranxi & Pseudocaranx dentex & Carangidae & Australia & 5 \\
\hline E. cheilodactyli & Cheilodactylus variegatus & Cheilodactylidae & Chile & 3 \\
\hline E. embiotocae & Amphistichus argenteus & Embiotocidae & California USA & 5 \\
\hline E. embiotocae & Cymatogaster aggergata & Embiotocidae & California USA & 5 \\
\hline E. haemuli & Orthorpistis ruber & Haemulidae & Brazil & $\begin{array}{l}\text { This } \\
\text { study }\end{array}$ \\
\hline E. kuwaitensis & Caranx sexfasciatus & Carangidae & Mediterrano & 5 \\
\hline E. kuwaitensis & Caranx sp. & Carangidae & Arabian Gulf & 5 \\
\hline E. kuwaitensis & Plectorhinchus shotaf & Haemulidae & Arabian gulf & 47 \\
\hline E. Iutjani & Lutjanus johni & Lutjanidae & India & 5 \\
\hline E. pagrosomi & Caulolatilus princeps & Malacanthidae & Peru & 48 \\
\hline E. pagrosomi & Caulolatilus sp. & Malacanthidae & Galapagos Islands & 5 \\
\hline E. pagrosomi & Chrysophrys auratus & Sparidae & Australia & 5 \\
\hline E. pagrosomi & Haemulon steindachneri & Haemulidae & Venezuela & 49 \\
\hline E. pagrosomi & Orthopristis ruber & Haemulidae & Venezuela & 49 \\
\hline E. pagrosomi & Pagrosomus auratus & Sparidae & Australia & 5 \\
\hline E. pagrosomi & $\begin{array}{l}\text { Pomadasys } \\
\text { macracanthus }\end{array}$ & Haemulidae & Mexico & 5 \\
\hline E. souzalimae & Thyrsitops lepidopoides & Gempylidae & Brazil & 24 \\
\hline E. souzalimae & Trichiurus lepturus & Trichiuridae & Brazil & 7 \\
\hline E. spari & $\begin{array}{l}\text { Acanthopagrus } \\
\text { bifasciatus }\end{array}$ & Sparidae & Arabian Gulf & 47 \\
\hline
\end{tabular}




\begin{tabular}{|c|c|c|c|c|}
\hline E. spari & Anisotremus surinamensis & Haemulidae & Brazil & 25 \\
\hline E. spari & Argyrops spimniofer & Sparidae & Arabian Gulf & 47 \\
\hline E. spari & Carangoides bajad & Carangidae & Arabian Gulf & 47 \\
\hline E. spari & Conodon nobilis & Haemulidae & Brazil & 25 \\
\hline E. spari & Epinephelus akaara & Serranidae & Japan & 5 \\
\hline E. spari & Gymnocranius griseus & Lethrinidae & Vietnam & 5 \\
\hline E. spari & Haemulon sciurus & Haemulidae & Brazil & 5 \\
\hline E. spari & Lethrinus nebulosus & Lehtrinidae & Japan & 5 \\
\hline E. spari & Menticirrhus americanus & Sciaenidae & Brazil & 20 \\
\hline E. spari & Micropogonias furnieri & Sciaenidae & Brazil & 25 \\
\hline E. spari & Nemipterus virgatus & Nemipteridae & Japan & 5 \\
\hline E. spari & Orthopristis ruber & Haemulidae & Brazil & 22 \\
\hline E. spari & Pagrus major & Sparidae & Japan & 5 \\
\hline E. spari & Pagrus pagrus & Sparidae & Brazil & 26 \\
\hline E. spari & Parapristipoma trilineatus & Haemulidae & Japan & 5 \\
\hline E. spari & Plectorhinchus cinctus & Haemulidae & Arabian Gulf & 6 \\
\hline E. spari & Plectorhinchus pictus & Haemulidae & Arabian Gulf & 5,6 \\
\hline E. spari & Plectorhinchus schotaf & Haemulidae & Arabian Gulf & 6 \\
\hline E. spari & Plectorhinchus sp. & Haemulidae & Vietnam & 5 \\
\hline E. spari & Plectorhinchus spp. & Haemulidae & Arabian Gulf & 47 \\
\hline E. spari & Sebastes inermis & Sebastidae & Japan & 5 \\
\hline E. spari & Sparus aurata & Sparidae & Mediterranean Sea & 51 \\
\hline E. spari & Sparus macrocephalus & Sparidae & Japan & 5 \\
\hline E. spari & Umbrina canosai & Sciaenidae & Argentina & 50 \\
\hline E. spari & Upeneus tragula & Mullidae & Japan & 5 \\
\hline E. xiamenesis & Pagrosomus major & Sparidae & Taiwan & 44 \\
\hline E. yamagutii & Pagrus pagrus & Sparidae & Brazil & $\begin{array}{l}\text { This } \\
\text { study }\end{array}$ \\
\hline
\end{tabular}

* Lethrinus chrysostomus reported as host for E. caballeroi is a synonymous for Lethrinus miniatus.

\section{Figures}




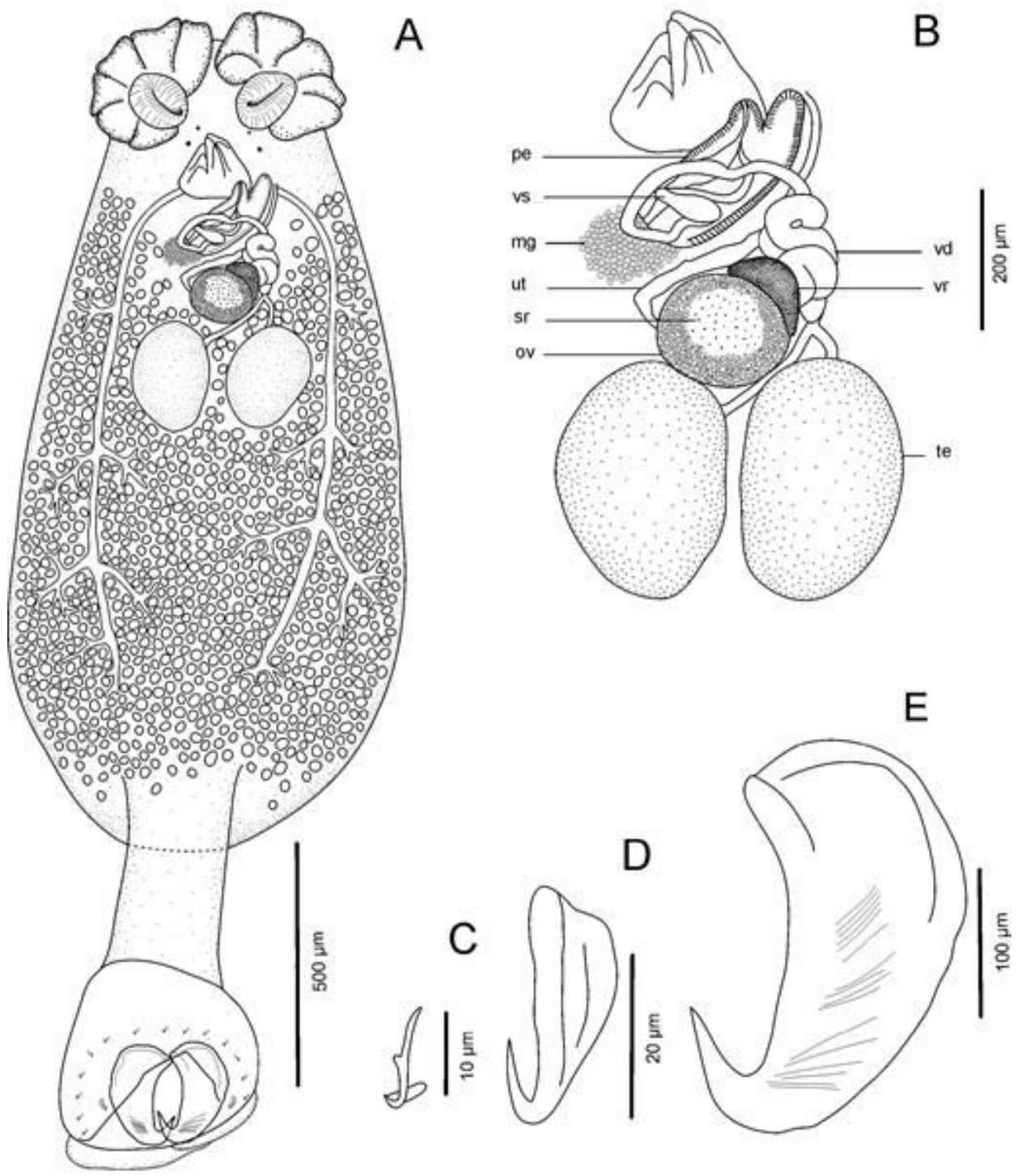

Figure 1

Encotyllabe yamagutii n. sp. ex Pagrus pagrus. A Ventral view of the holotype. B Reproductive system. C Marginal hooklets. D Small hamuli. E Large hamuli. Abbreviations: pe, penis; vs, seminal vesicle; mg, Mehlis' gland; ut, uterus; sr, seminal receptacle; ov, ovary; te, testes; vr, vitelline reservoir; vd, vas deferens. 

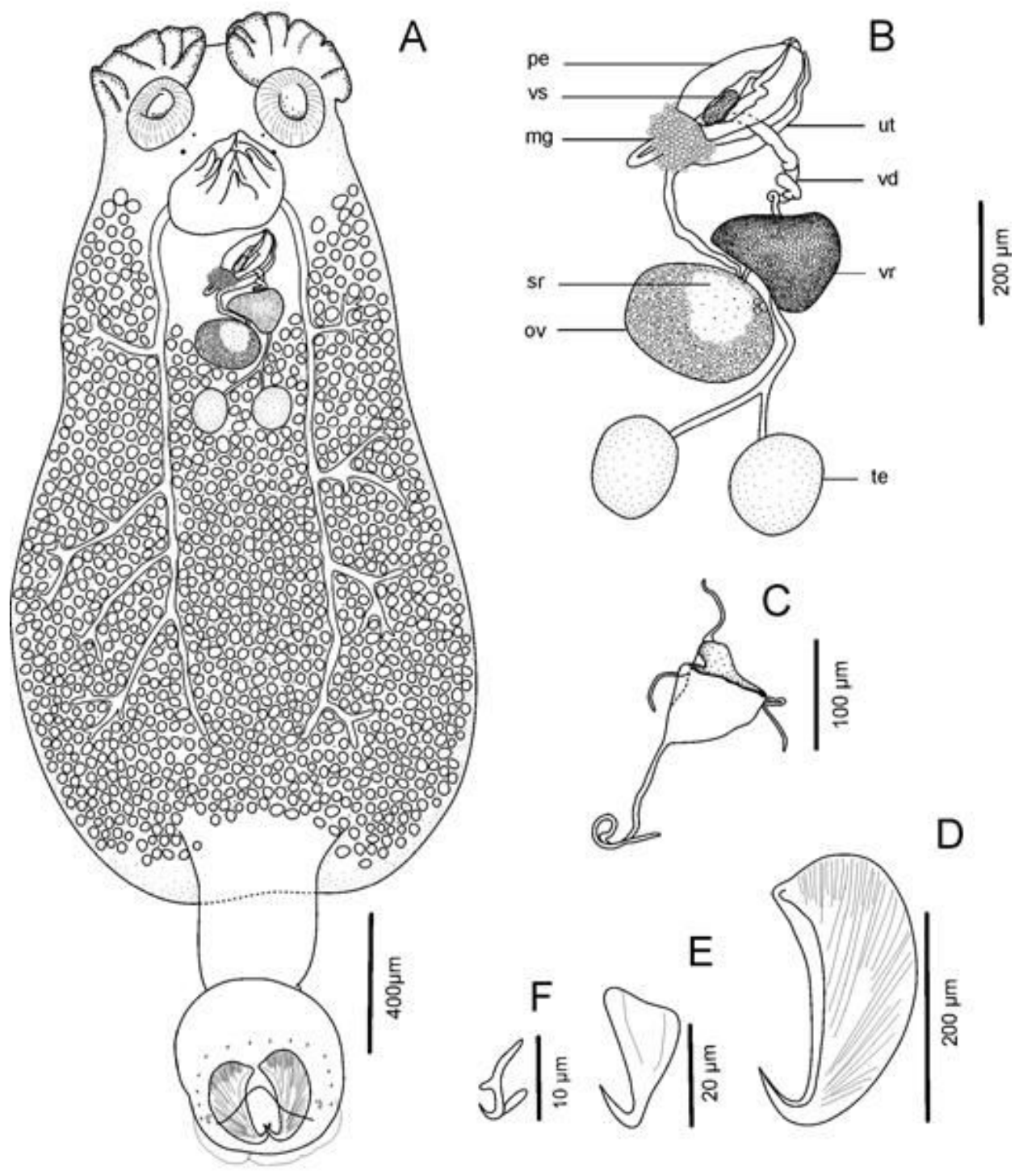

Figure 2

Encotyllabe haemuli n. sp. ex Orthopristis ruber. A Ventral view of the holotype. B Reproductive system. C egg. D Marginal hooklets. E Small Hamulus. F Large hamulus. Abbreviations: pe, penis; vs seminal vesicle; mg, Mehlis' gland; sr, seminal receptacle; ov, ovary; te, testes; vr, vitelline reservoir; vd, vas deferens; ut, uterus. 


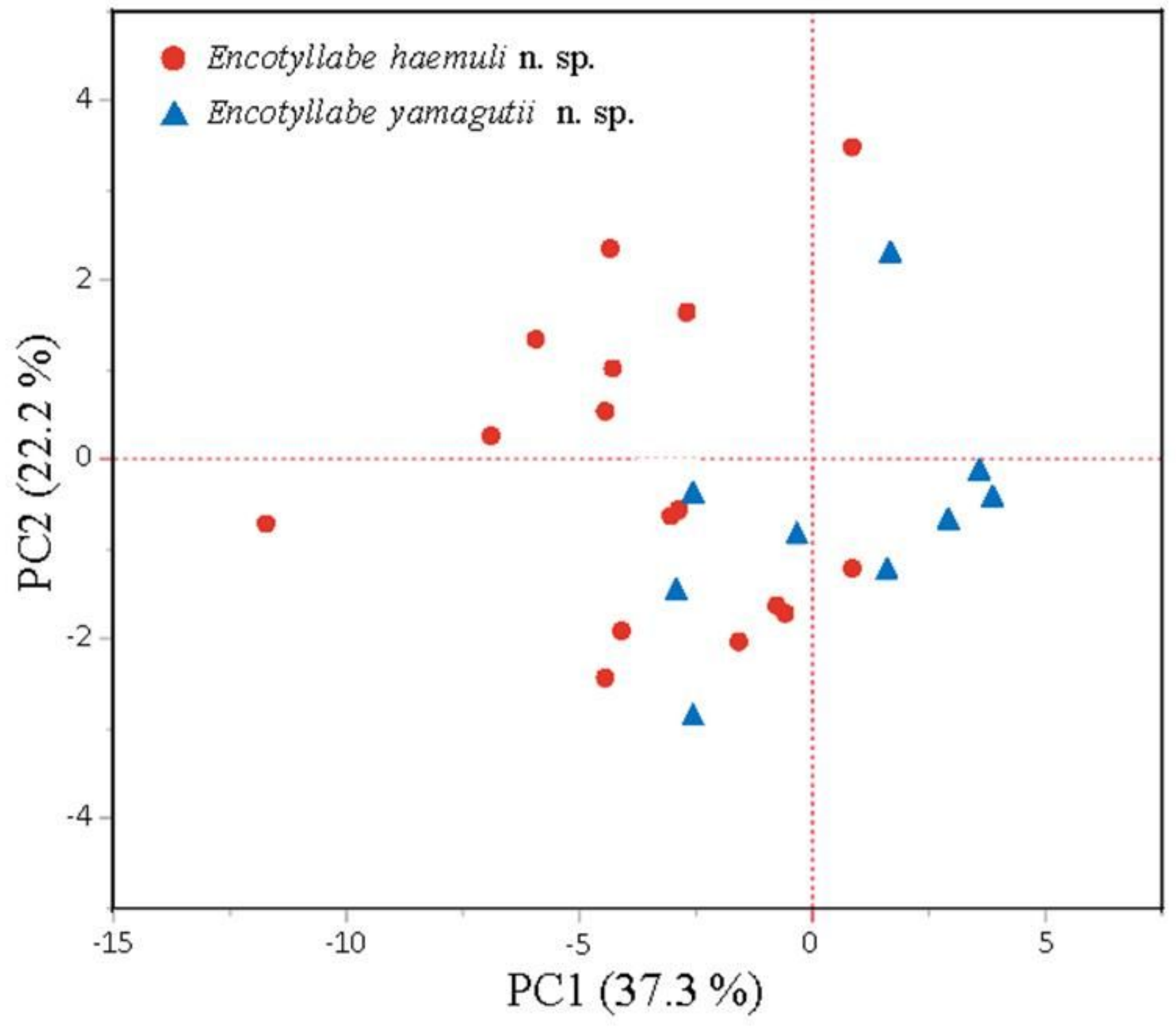

Figure 3

Principal components analysis based on proportional morphometric measurements standardized by total length from the new species of Encotyllabe from Brazil. Red circles: E. haemuli ex Orthopristis ruber; Blue triangle E. yamagutii n. sp. ex Pagrus pagrus. 


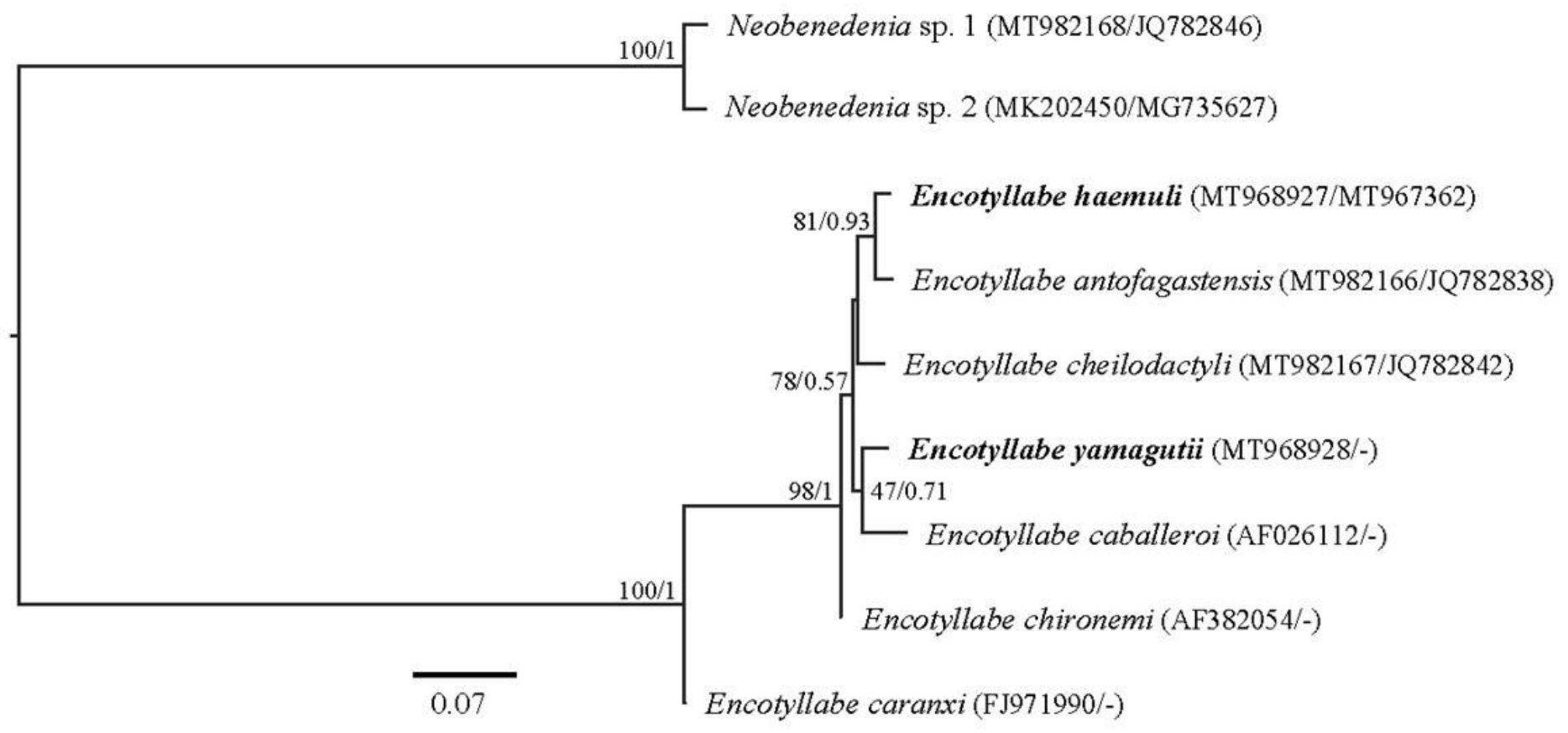

\section{Figure 4}

Phylogenetic tree based on concatenated LSU rRNA and cox1 genes for Encotyllabe spp. inferred by Maximum Likelihood (ML) and Bayesian inference (BI). Numbers along branches indicate the bootstrap values obtained from the posterior probability support of 1000 replicates for the Maximum Likelihood analysis and posterior probability of Bayesian Inference (ML/PP). 